\title{
Advances of Quantitative IR-Thermal Imaging in Medical Diagnostics
}

\author{
A. Z. Nowakowski \\ Department of Biomedical Engineering, Gdansk University of Technology, Gdansk, Poland
}

\begin{abstract}
This review will show the state of the art in thermal IR-imaging from the point of view of medical diagnostics. Advantages and limitations of IR thermal imaging, including tomography procedures, based on thermal properties of living tissues, will be presented. Properties of this modality will be discussed mainly from the point of view of skin burn evaluation.
\end{abstract}

Keywords-thermal tissue properties, thermal tomography, medical diagnostics

\section{INTRODUCTION}

Living organism may be regarded as a source of different signals, which are interpreted from the point of view of medical diagnostics. IR thermal imaging is known as a very important modality in determination of local sources of hot or cold spots (increased or decreased metabolism), e.g. showing places of cancer development or deficit of blood flow.

The goal of this presentation is to discuss the diagnostic role of thermal tissue properties. The main questions concern such problems as limitations in investigation of living organs, diagnostic meaning of measurements, etc. Advances in construction of measurement systems will be shortly presented.

The discussion is illustrated by solutions and measurements performed at the Department of Biomedical Engineering Gdansk University of Technology (TUG) in cooperation with several clinics of Medical University of Gdansk (MUG) and the Department of Animal Physiology of Gdansk University (UG).

\section{INFRARED THERMAL IMAGING}

Infrared thermal imaging is present in medical diagnostics for almost 50 years [1,2,3,4,5]. Unfortunately lack in preserving standard "golden rules" in diagnostic procedures evoked a great critical dispute of the value of thermography in medical diagnostics [6] and as a result, this modality was almost forgotten. This was a mistake as IR thermal imaging has a lot of advantages. It is non-contact, therefore aseptic and safe, gives no interaction with tissues, it is fast and easy to use; storage of data is simple as well as presentation of surface temperature is very attractive. Recently one may observe a great progress of this technology, what makes it extremely attractive again. Advances of thermography in medicine are presented in several books, as e.g. [7]. Broad bibliography of classical thermography in medicine is available in Glamorgan University [8]. At present in USA several institutions are strongly involved in promotion of new ideas in IR thermal imaging, e.g. $[9,10,11]$. In Europe very active is the group of institutions acting in the field of non-destructive testing Quantitative Infrared Thermography QIRT [12,13]; in medicine new projects concern standardization of procedures $[14,15,16]$. Also in Poland some publications are dealing with IR imaging in medicine $[17,18,19]$.

In most of those publications classical IR thermal imaging methods are described. Distribution of the body surface temperature, usually as a steady state, frequently based on observation of symmetries, is holding diagnostic information. Living organism itself is generating heat; therefore distribution of surface temperature may be giving a lot of information, which has important diagnostic value. Advances in IR instrumentation, especially increased thermal resolution and implementation of digital signal processing, also introduction of new matrices of FPA detectors (Focal Plane Array) are pushing this technology and made it is easy accessible. In medical applications cameras of the speed of 30 frames/second, thermal resolution at the level of $0.1{ }^{\circ} \mathrm{C}$ and pixel resolution $240 \times 320$, with handy room temperature operation, are fully acceptable in practice. Also prices of such cameras are falling down, what makes this equipment to be accessible even in private practice. In research much better cameras of thermal resolution even at the level of $0.01{ }^{\circ} \mathrm{C}$ and with high time \& spatial resolution (respectively more than 1000 frames/second and 1 million pixels) are already available. Adding advances in computer technology, data processing and visualization one may claim this is a real technological revolution in IR thermal imaging.

Such trends as use of digital analysis of enhanced resolution thermal images [20], advanced model based analysis of thermal objects [21] or of characteristic thermal signatures $[9,22]$ are representing the modern approaches. Important are projects concerning accessible from the global net databases containing reference data for normal, healthy and diagnosed cases $[15,23]$. Important are methods using advanced quantitative statistic analysis of images [24,25], or some other advanced mathematic tools, as e.g. neural networks [26], thermal texture maps [27] or extraction of functional features of thermal images [28]. Another interesting proposal concerns very fast registration of thermal images and Fourier analysis, allowing presentation of very subtle temperature changes [29]. Unfortunately, here a high performance camera is necessary.

Probably first active dynamic thermography experiments for medical diagnostics have been proposed in VUB [30]. The microwave energy was applied to enhance 
thermal effects of breast cancer. At this time Vavilov [31] introduced for the first time the term Thermal Tomography.

Thermal Tomography allows identification of geometry of a tested object based on thermal properties of tissues. Generally, thermal excitation applied to a tested object is responsible for temperature transients on its surface. Results of measurements of surface transient processes are compared with results of simulations of an equivalent model of the object. Solving the inverse problem the internal structure of the object of known thermal properties or thermal properties for defined object geometry may be calculated. We are intensively involved in development of active dynamic thermography (ADT) as well as thermal tomography (TT) in such medical applications as: classification of skin burns, inspection of cardiosurgical interventions, detection of the breast cancer and some other.

The main difference comparing $\mathrm{ADT}$ and $\mathrm{TT}$ to classical thermal imaging is in investigation of thermal properties of tissues, not just simple distribution of temperature. In both techniques external excitation is applied and thermal transients are registered. Usually, based on an equivalent thermal model, a tested structure is determined or some synthetic parameters, strongly correlated to this structure are visualized. We proved the value of such measurements in in vivo animal experiments and in clinics [32 - 45], where basic limitations of both methods have been analyzed and defined. The conclusions show different meaning of both modalities and their special role as monitoring techniques.

We asked the following questions:

$>$ What is the practical value of ADT and TT?

$>$ Could ADT and TT be used for reliable intra-operation monitoring in cardiosurgery interventions, in skin burn evaluation, in mammography, etc.?

Concluding, even thermal properties of different tissues may be not strong the heat transfer by blood is responsible for getting strong contrast in thermal images. ADT and TT are limited to rather thin layers, as the skin is, where evaluation of burns was proved to be efficient. Both modalities may be used for evaluation of tissues of affected vascularisation. Method's surface resolution depends on optical system and may be very high. ADT and TT are non-contact, assuring aseptic applications. Still, limited knowledge of emissivity is influencing accuracy of data acquisition.

Depending on time I may also compare TT and EIT (electrical impedance tomography) - Is there any correlation between thermal and electrical properties of biological tissues?

The main element of comparison is the relation of thermal and electrical parameters, which are shown in Tab.1. The values are of approximate character, as a big diversity of different parameter values for a living tissue exists. It is clearly seen that thermal properties do not differ importantly; therefore it would be difficult to use TT for discrimination of deep internal body structure. Much better situation is in electrical domain, where properties of different tissues are better differentiated. Additional factor limiting TT is slow speed of thermal transients, what always should be taken into account.

Table 1. Thermal and electrical parameters of different tissues (approximate values taken from measurements and literature)

\begin{tabular}{|c|c|c|c|c|}
\hline Parameter & $\begin{array}{l}\text { Density } \\
\Delta \\
{\left[\mathrm{kg} / \mathrm{m}^{3}\right]}\end{array}$ & $\begin{array}{c}\text { Thermal } \\
\text { conductivity } \\
k \\
{[\mathrm{~W} /\{(\mathrm{m})(\mathrm{K})\}]}\end{array}$ & $\begin{array}{c}\text { Thermal } \\
\text { effusivity } \\
\beta \\
{\left[\mathrm{J} /\left(\mathrm{m}^{2} \mathrm{Ks}^{1 / 2}\right)\right]}\end{array}$ & $\begin{array}{c}\text { Electrical } \\
\text { conductivity } \\
\sigma \\
{[\mathrm{S} / \mathrm{cm}]} \\
\end{array}$ \\
\hline Heart muscle & 1060 & 0.53 & 1440 & $2.510^{-3}$ \\
\hline $\begin{array}{l}\text { Skeletal } \\
\text { muscle } \\
\text { transverse } \\
\end{array}$ & 1044 & 0.49 & 1370 & $0,6210^{-3}$ \\
\hline $\begin{array}{l}\text { Skeletal } \\
\text { muscle } \\
\text { longitudinal } \\
\end{array}$ & 1045 & 0.49 & 1370 & $\begin{array}{l}(3.35-7.4) \\
10^{-3}\end{array}$ \\
\hline Brain & 1034 & 0.54 & 1440 & $1.710^{-3}$ \\
\hline Kidney & 1050 & 0.51 & 1404 & $2.710^{-3}$ \\
\hline Liver & 1060 & 0.53 & 1280 & $\begin{array}{l}(1.2-2.7) \\
10^{-3}\end{array}$ \\
\hline Lungs & 1050 & 0.39 & 1100 & $\begin{array}{l}(0.4-0.94) \\
10^{-3}\end{array}$ \\
\hline Fat & 850 & 0.22 & 725 & $0.33510^{-3}$ \\
\hline Blood & 1060 & 0.49 & 1370 & $6.710^{-3}$ \\
\hline
\end{tabular}

Tomography is giving in each case data of great importance in terms of the evaluation of surgical procedures as well as visualization of actual state of the tested heart. Electroimpedance measurements allow direct inspection of the state of the heart. The main disadvantage is that only contact measurements are possible, limiting the spatial resolution of the method to dimensions dependent on the electrode size and position. Only surfaces accessible for measurements may be inspected. Electroimpedance measurements are giving local information of the state of inspected tissue while IR imaging shows full structure. Both modalities allow easy discrimination of necrosis as well as of increased vascularisation. In both cases quantitative data describe objective state of the tissue under investigation, allowing application of advanced digital data processing important for proper diagnosis. Electrical measurements are cheaper although direct contact, e.g. to the heart tissue, is necessary causing a lot of aseptic problems.

\section{ACKNOWLEDGMENT}

The author thanks the co-workers and Ph.D. students from TUG, MUG and UG, who participated in the presented research. Most of the names are listed in the attached bibliography as co-authors of common publications. 


\section{REFERENCES}

[1] Williams K. L., Williams F. L., Handlay R. S., Infrared radiation thermometry in clinical practice, Lancet, 1960, 958.

[2] Williams K. L., Williams F. L., Handlay R. S., Infrared thermometry in the diagnosis of breast disease, Lancet, 1961, 1378 - 1381.

[3] Lawson R. N., Chughtai M. S., Breast cancer and body temperature, Can. Med. Ass. J., v. 82, no 2, 1963, 68.

[4] Barnes R. B., Gerson-Cohen J., Thermography of the human body, Science, v. 140, 1963, 870-877.

[5] Gershen-Cohen J., Haberman J. Brueschke E. E., Medical thermography: A summary of current status, Radiol. Clin. North Am., 1965, 3, 403-431.

[6] Report of the Working Group to Review the National Cancer Institute Breast Cancer Detection Demonstration Projects, Journal of National Cancer Institute, v. 62, 1979, 641-709.

[7] Nowakowski A., Kaczmarek M., Hryciuk M., Ruminski J., Advances in thermography - medical applications (in Polish), Wyd. Gdanskie, Gdansk, 2001.

[8] Jones B. Ed. CD - Acta Thermogrphica \& Thermology Archive of Papers, University of Glamorgan, 2000;

[9] Paul J.L., Lupo J.C., Application of infrared imaging and automatic target recognition image processing for early detection of breast cancer, IEEE Eng. in Medicine and Biology, v. 21, 6, 2002, 34 - 35.

[10] Qi H., Diakides N., Thermal infrared imaging in early breast cancer detection - a survey of recent research, Proc. IEEE EMBC, Cancun, $2003,1109-1112$

[11] Kayserlink J., Ahlgren P., Yassa M., Belliveau N., Overview of functional infrared imaging as part of a multi-imaging strategy for breast cancer detection and therapeutic monitoring, Proc. EMBSBMES Conf., Houston, 2002, 231.

[12] Proc. QIRT, Chatenay-Malabary-1992, Naples-94, Stuttgart-1996, Lodz-1998, Venice-2000, Reims-2002, Brussels-2004.

[13] QIRT Journal, published since April 2004.

[14] Ring E.F.J., Standardisation of Thermal Imaging Technique, Thermology Oesterrich, 3, 1993, 11 - 13.

[15] http://www.comp.glam.ac.uk/pages/staff/pplassma/MedImaging/Proje cts/IR/Atlas/index.htm

[16] Ammer K., Ring E.F.J., Plassmann P., Jones B.F., Rationale for standard capture and analysis of infrared images, IFMBE Proc. 2-nd European Medical and Biological Engineering Conf., Vienna, 2002, $1608-1609$

[17] Jung A., _uber J., Ring F., A casebook of infrared imaging in clinical medicine, Medpress, Warsaw, 2003.

[18] Nowakowski A., Wrobel Z., IR thermography in medical diagnostics, in Polish, 475 - 614; Nowakowski A., Kaczmarek M., Hryciuk M., Thermal Tomography, 615 - 696, in Chmielewski L., Kulikowski J.L., Nowakowski A., Obrazowanie Biomedyczne, Biocybernetyka $i$ In_ynieria Biomedyczna 2000, v. 8, EXIT, Warszawa, 2003.

[19] Thermovision Measurements in Practice (in Polish - Pomiary Termowizyjne $w$ Praktyce, Praca zbiorowa), Agenda Wydawnicza $\mathrm{PAKu}$, Warszawa, 2004.

[20] Arena F., Barone C., DiCicco T., Use of digital infrared imaging in enhanced breast cancer detection and monitoring of the clinical response to treatment, Proc. IEEE EMBEC Conf., Cancun, 2003, $1129-1132$

[21] Nowakowski A., Kaczmarek M., Ruminski J., Hryciuk M., Renkielska A., Grudzinski J., Siebert J., Jagielak D., Rogowski J., Roszak K., Stojek W., Medical applications of model based dynamic thermography, Proc. SPIE, v. 4360, 2001, $492-503$.

[22] Irvine J.M., Applicability of automated target recognition technique to early screening for breast cancer, IEEE Eng. in Medicine and Biology, v. $21,6,36-40,2002$

[23] Murawski P., Jung A., _uber J., Kalicki B., The project of an open and extendable database for thermal images archiving, IFMBE Proc. 2-nd European Medical and Biological Engineering Conf., Vienna, $2002,1618-1619$.
[24] Jones B., Plassman P., Computational approaches to image processing for improved interpretation and analysis, IEEE Eng. in Medicine and Biology, v. 21, 6, 2002, 41 - 48.

[25] Jakubowska T., Wiecek B., Wysocki M., Drews-Peszynski C., Thermal signatures for breast cancer screening comparative study, Proc. IEEE EMBEC, Cancun, 2003, 1117-20.

[26] Szu H., Kopriva I., Hoekstra P., Diakides N., Diakides M., Buss J., Lupo J., Early Tumor Detection by Multiple Infrared Unsupervised Neural Nets fusion, Proc. IEEE EMBC, Cancun, 2003, 1133 - 1136.

[27] Qi H., Kuruganti P.T., Liu Z., Early detection of breast cancer using thermal texture maps, IEEE Int. Symp. On Biomedical Imaging, Washington DC, 2002, $309-312$.

[28] Keyserlingk J. R., Ahlgren P. D., Yu E., Belliveau N., Yassa M., Functional Infrared Imaging of the Breast, IEEE Engineering in Medicine and Biology Magazine, vol. 19, No 3, 2000, 30-42.

[29] Anbar M., Physiological, clinical and psychological applications of dynamic infrared imaging, Proc. IEEE EMBC, Cancun, 2003, 1121 1123.

[30] Steenhaut O., Van Denhaute E., Cornelis J., Contrast enhancement in infrared thermography by the application of microwave irradiation applied to tumour detection, Proc. MECOMBE'86, 1986, 485-488.

[31] Vavilov V., Shirayev V., Thermal Tomograph - USSR Patent no. $1.266 .308,1985$

[32] Nowakowski A, Kaczmarek M., Dynamic thermography as a quantitative medical diagnostic tool, Medical and Biological Eng. and Computing incorp. Cellular Eng., 37, suppl.1, p.1, 1999, 244 - 245.

[33] Kaczmarek M., Ruminski J., Nowakowski A., Measurement of thermal properties of biological tissues - Comparision of Different Thermal NDT Techniques, Proc. Advanced Infrared Technology and Application, Venice 1999, 2001, 322-329.

[34] Kaczmarek M., Nowakowski A., Renkielska A., Rating Burn Wounds by Dynamic Thermography, Quantitative InfraRed Thermography 5 , $2000,376-381$.

[35] Nowakowski A., Kaczmarek M., Debicki P., Active thermography with Microwave Excitation, Quantitative InfraRed Thermography 5, $2000,387-392$.

[36] Ruminski J., Nowakowski A., Kaczmarek M., Hryciuk M., Modelbased parametric images in dynamic thermography, Polish Journal of Medical Physics and Eng., 6(3), 2000, 159-164.

[37] Ruminski J., Kaczmarek M., Nowakowski A., Medical Active Thermography - A New Image Reconstruction Method, Lecture Notes in Computer Science, LNCS 2124, Springer, Berlin-Heidelberg, 2001, 274-181.

[38] Hryciuk M., Nowakowski A., Renkielska A., Multilayer thermal model of healty and burned skin, Proc. 2nd European Medical and Biological Engineering Conference, EMBEC'02, v. 3, Pt. 2., Vienna, 2002, 1614-1617.

[39] Nowakowski A., Kaczmarek M., Siebert J., Rogowski J., Jagielak D., Roszak K., Stojek W.,Topolewicz J., Role of Thermographic Inspection in Cardiosurgery, ibid., 1626-1627.

[40] Hryciuk M., Nowakowski A., Evaluation of thermal diffusivity variations in multi-layered structures, Proc. 6 QIRT, Zagreb, 2003, 267-274.

[41] Kaczmarek M., Rumunski J., Nowakowski A., Renkielska A., Grudzinski J., Stojek W., In-vivo experiments for evaluation of new diagnostic procedures in medical thermography, ibid., 260-266.

[42] Kaczmarek M., Nowakowski A., Analysis of Transient Thermal Processes for Improved Visualization of Breast Cancer Using IR Imaging, Proc. IEEE EMBC, Cancun, 2003, 1113-1116.

[43] Nowakowski A, Kaczmarek M., Wtorek J., Siebert J., Jagielak D., Roszak K., Topolewicz J., Thermographic and electrical measurements for cardiac surgery inspection, Proc. of 23rd Annual International Conference IEEE EMBS, CD-ROM, Istanbul, 2001.

[44] Renkielska A., Nowakowski A., Kaczmarek M., Dobke M.K., Grudzinski J., Karmolinski A., Stojek W.. Static thermography revisited - an adjunct method for determining the depth of the burn injury. Burns 2005, 31: 768-775.

[45] Renkielska A., Nowakowski A., Kaczmarek M., Ruminski J., Burn depth evaluation based on IR thermal imaging - a preliminary study", Burns 2006, accepted for publication. 